\title{
JNPH
}

Volume 7 No. 2 (Oktober 2019)

(C) The Author(s) 2019

\section{PENGARUH KONSUMSI AIR HANGAT TERHADAP FREKUENSI NAFAS PADA PASIEN ASMA DI PUSKESMAS SUKAMERINDU KOTA BENGKULU TAHUN 2019}

\author{
EFFECT OF WARM WATER CONSUMPTION OF BREATHING FREQUENCY IN \\ ASMA PATIENTS AT SUKAMERINDU COMMUNITY HEALTH CENTERS OF \\ BENGKUL CITY IN 2019
}

\author{
SRI HARDINA, SEPTIYANTI, DWI WULANDARI \\ FIKES UNIVED BENGKULU
}

\begin{abstract}
ABSTRAK
Asma terjadi akibat gangguan pada sistem pernapasan yang menyebabkan penderita mengalami mengi (wheezing), sesak napas, batuk, dan sesak di dada tertama ketika malam hari atau dini hari. Tujuan penelitian ini adalah untuk mengetahui pengaruh konsumsi air hangat terhadap Frekuensi Nafas Pada pasien asma Di Puskesmas Sukamerindu Kota Bengkulu Tahun 2019. Metode yang digunakan adalah Quasi Eksperimen, two group test design with control group, sampel diambil sebanyak 24 orang dengan teknik purposive sampling. Hasil penelitian dengan analisis Uji Univariat Karakteristik penderita asma di Puskesmas Sukamerindu Kota Bengkulu yaitu 19 orang $(67,9 \%)$ berjenis kelamin laki-laki, 22 orang $(78,6 \%)$ berusia $\geq 19$ tahun dan lama menderita asma 18 orang $(64,3 \%)<5$ tahun. Rata-rata frekuensi pernafasan pada kelompok kontrol sebelum $(26,42)$ dan setelah $(26,50)$, Rata-rata frekuensi pernafasan pada kelompok kasus sebelum $(26,92)$ dan setelah $(26,28)$. Hasil bivariat yaitu tidak ada pengaruh frekuensi nafas pada pasien asma sebelum dan setelah pada kelompok kontrol (tidak konsumsi air hangat), ada pengaruh frekuensi nafas pada pasien asma sebelum dan setelah pada kelompok intervensi (konsumsi air hangat). Ada pengaruh frekuensi nafas pada pasien asma kelompok post kasus dan kelompok post kontrol di Puskesmas Sukamerindu Kota Bengkulu Tahun 2019 Peneliti menyarankan pihak Puskesmas diharapkan dapat memberikan penyuluhan tentang manfaat konsumsi air hangat sebagai terapi alternative pada pengobatan asma.
\end{abstract}

Kata Kunci: Asma, Konsumsi Air Hangat

\begin{abstract}
Asthma is caused by a disturbance in the respiratory system that causes sufferers to experience wheezing, shortness of breath, coughing, and tightness in the chest especially at night or early morning. The purpose of this study was to determine the effect of consumption of warm water on breath frequency in asthma patients at the Sukamerindu Public Health Center in Bengkulu City in 2019. The method used was Quasi Experiment, two group test design with control group, samples were taken as many as 24 people with purposive sampling technique. The results of the study with the analysis of the Characteristics Univariate Test of asthma sufferers in the Sukamerindu Public Health Center in Bengkulu City were 19 people $(67.9 \%)$ male sex, 22 people $(78.6 \%)$ aged $\geq 19$ years and had asthma 18 people $(64,3 \%)<5$ years. The average
\end{abstract}


respiratory frequency in the control group before (26.42) and after (26.50), the average respiratory frequency in the case group before (26.92) and after (26.28). The bivariate results were that there was no effect of breath frequency in asthma patients before and after in the control group (no consumption of warm water), there was an influence of breath frequency in asthma patients before and after in the intervention group (warm water consumption). There is an influence of breath frequency on asthma patients in post case and post control groups in Sukamerindu Public Health Center in Bengkulu City in 2019. Researchers suggest that Puskesmas can provide counseling about the benefits of consuming warm water as an alternative therapy in the treatment of asthma.

\section{Keywords: Asthma, Consumption of Warm Water}

\section{PENDAHULUAN}

Asma disebut sebagai penyakit kronis bronkial. Asma merupakan suatu keadaan dimana saluran nafas mengalami penyempitan karena hiperaktivitas terhadap rangsangan tertentu, yang menyebabkan peradangan, penyempitan ini bersifat berulang namun reversible dan diantara episode penyempitan bronkus. Asma terjadi akibat gangguan pada sistem pernapasan yang menyebabkan penderita mengalami mengi (wheezing), sesak napas, batuk, dan sesak di dada tertama ketika malam hari atau dini hari (Amin dan Hardhi, 2016).

Laporan Organisasi Kesehatan Dunia (WHO) tahun 2016 dalam World Health Report menyebutkan, lima penyakit paru utama merupakan $17,4 \%$ dari seluruh kematian di dunia, masing-masing terdiri dari infeksi paru 7,2\%, PPOK (Penyakit Paru Obstruksi Kronis) 4,8\%, Tuberkulosis 3,0\%, kanker paru/trakea/bronkus $2,1 \%$ dan Asma 0,3\%. Menurut Global initiative for asthma (GINA) tahun 2016 memperkirakan 300 juta penduduk dunia menderita asma. Prevalensi total asma di dunia diperkirakan $6 \%$ pada dewasa dan $10 \%$ pada anak (Infodatin, 2017).

Berdasarkan Profil Kementrian Kesehatan RI Tahun 2017 menyebutkan bahwa 1 dari 22 orang di Indonesia menderita asma. Namun, hanya 54\% yang didiagnosis dengan hanya 30\% kasus terkontrol dengan baik. Prevalensi asma di Indonesia mencapai $4,5 \%$ atau setara dengan 11,8 juta pasien. Hanya $29 \%$ dari populasi penderita dewasa penyakit asma yang dirawat, sisanya tidak terawat atau terawat sebagian. Prevalensi asma tertinggi terdapat di Sulawesi Tengah (7,8\%), diikuti Nusa Tenggara Timur (7,3\%), D.I. Yogyakarta $(6,9 \%)$, dan Sulawesi Selatan $(6,7 \%)$. Sedangkan provinsi dengan prevalensi terendah terdapat di Lampung $(1,6 \%)$, Riau $(2,0 \%)$ dan Bengkulu $(2,0 \%)$ (Kemenkes RI, 2017).

Berdasarkan data dari Dinas Kesehatan Kota Bengkulu menyebutkan bahwa jumlah penderita asma tertinggi yaitu Puskesmas Pasar Ikan 43 orang, Puskesmas Basuki Rahmad sebanyak 43 orang dan Puskesmas Sukamerindu sebanyak 35 orang. Berdasarkan data tersebut salah satu puskesmas yang perawatan 24 jam yaitu puskesmas Sukamerindu pada usia 20-59 tahun sebanyak 22 orang (Dinkes Kota Bengkulu, 2018).

Penelitian yg dilakukan oleh National Health Interview tahun 2012, mengatakan bahwa akibat dari asma yang tidak ditangani dengan tepat dapat menyebabkan kematian. Penelitian tersebut mengatakan bahwa asma merupakan penyebab kematian kedelapan dari data yg ada di Indonesia prevalensi gejala penyakit asma melonjak dari $4,2 \%$ jadi $5,4 \%$ (Ekarini, 2012).

Penyebab penyakit asma ada kaitannya dengan antibodi tubuh yang memiliki kepekaan berlebih terhadap alergen dalam hal ini adalah Imunoglobulin (Ig) E. Sedangkan alergen yang dimaksud disini dapat berupa alergen intrinsik maupun ekstrinsik. Sehingga penyakit asma ini dapat menurun dari orang tua kepada keluarganya (Kowalak et all, 
2011).

Salah satu masalah yang diakibatkan oleh asma menurut Sari (2016) adalah adanya penumpukan sputum pada saluran pernapasan. Beberapa gejala klinis akibat penumpukan sputum ini adalah pernapasan cuping hidung, peningkatan respiratory rate, Dyspnea, timbul suara krekels saat diauskultasi, dan kesulitan bernapas. Kesulitan bernapas akan menghambat pemenuhan suplai oksigen dalam tubuh sehingga suplai oksigen berkurang. Berkurangnya suplai oksigen dalam tubuh akan membuat kematian sel, hipoksemia dan penurunan kesadaran. Penanganan pada pasien asma dengan masalah kebersihan jalan napas bertujuan untuk membersihkan saluran pernapasan sehingga suplai oksigen yang masuk ke dalam tubuh dapat terpenuhi dan gangguan akibat berkurangnya suplai oksigen tidak terjadi.

Penatalaksanaan pada penyakit asma dapat dilakukan dengan cara farmakologi dan non farmakologi. Pengobatan farmakologis pada asma biasanya dengan oksigenisasi dan melibatkan pengobatan beta 2 adrenergik, sedangkan pengobatan nonfarmakologis biasanya dengan menghindari faktor penyebab dan menciptakan lingkungan yang sehat, selain itu dalam mengurangi gejala asma dan memperbaiki kualitas hidup yaitu dengan terapi pemberian air hangat. Namun mengingat banyaknya efek samping dari pengobatan farmakologi seperti sakit kepala dan pusing, gangguan tidur atau insomnia, merasa nyeri pada otot, hidung yang meler atau tersumbat, mulut dan tenggorokan terasa kering, batuk dan suara serak dan sakit tenggorokan. Jangka panjang dan kenyataannya bahwa gangguan-gangguan psikologis seperti cemas dan depresi berperan dalam kekambuhan asma, maka terapi komplementer saat ini banyak dimanfaatkan oleh pasien asma (Kusumawati, 2012).

Pemberian minum air putih hangat memberikan efek hidrostatik dan hidrodinamik dan hangatnya membuat sirkulasi peredaran darah khususnya pada daerahparu-paru agar menjadi lancar. Secara fisiologis, air hangat juga memberi pengaruh oksigenisasi dalam jaringan tubuh (Hamidin, 2012). Hal serupa diungkapkan oleh Yuanita (2011), minum air hangat dapat memperlancar proses pernapasan, karena pada pernapasan pasien asma membutuhkan suasana yang encer dan cair. Pada penderita asma minum air hangat sangat tepat untuk membantu memperlancar pernapasan karena dengan minum air hangat partikel-partikel pencetus sesak dan lendir dalam bronkioli akan dipecah dan menyebabkan sirkulasi pernapasan menjadi lancar sehingga mendorong bronkioli mengeluarkan lendir.

Penelitian yang dilakukan oleh Adiputra (2017) menyebutkan bahwa dari hasil uji Wilcoxon didapatkan $p$ value sebesar 0,002, yang menunjukkan bahwa terdapat pengaruh pemberian air minum hangat sebelum tindakan nebulizer terhadap frekuensi pernapasan pada pasien asma. Hasil uji Mann Whitney didapatkan $p$ value sebesar 0.029 , artinya terdapat perbedaan pengaruh pemberian air minum hangat sebelum tindakan nebulizer terhadap kelancaran jalan nafas yang dilihat dari frekuensi nafas dan derajat sesak nafas, perbedaan pada penelitian ini ialah perlakuan konsumsi air hangat yang diberikan saat akan melaukan terapi farmakologi nebulizer.

Berdasarkan survey awal yang dilakukan di Puskesmas Sukamerindu pada tanggal 18 Desember 2018 jumlah pasien penderita asma sebanyak 3 orang yang seluruh esponden belum mengetahui terapi nonfarmakolgi air hangat dapat menurunkan frekuensi sesak nafas pada penderita asma.

Berdasarkan latar belakang diatas, maka penulis tertarik dengan judul "Pengaruh Konsumsi Air Hangat terhadap Frekuensi Nafas Pada Pasien Asma Di Puskesmas Sukamerindu Kota Bengkulu Tahun 2019".

Rumusan masalah dalam penelitian ini adalah "Adakah Pengaruh Konsumsi Air Hangat terhadap Frekuensi Nafas Pada Pasien Asma Di Puskesmas Sukamerindu Kota Bengkulu Tahun 2019?'”. Tujuan penelitian adalah diketahui pengaruh konsumsi air hangat terhadap Frekuensi Nafas Pada pasien 
asma Di Puskesmas Sukamerindu Kota Bengkulu Tahun 2019?

\section{METODE PENELITIAN}

Desain dalam penelitian ini menggunakan desain penelitian quasy experiment menggunakan pendekatan two group test design with control group melalui pendekatan deskriptif kuantitatif. Populasi dalam penelitian ini adalah seluruh penderita asma di Puskesmas Sukamerindu Kota Bengkulu yang berjumlah 34 orang pada bulan Januari tahun 2019, sampel $13+1=14$ orang per grup. Jadi sampel dalam penelitian ini sampel sebanyak 28 orang yang terdiri dari 14 responden pada kelompok kasus dan 14 responden pada kelompok kontrol. Teknik pengambilan sampel yang digunakan peneliti adalah purposive sampling.

Untuk mendapatkan data dalam penelitian ini penulis menggunakan teknik pengumpulan data primer dan sekunder dengan proses penelitian sebelum mengkonsumsi air hangat peneliti mengetahui pengukuran tingkat frekuensi pernafasan pada penderita asma. Mengkonsumsi air hangat secara perlahan dalam waktu 5 menit. Setelah selesai mengkonsumsi air hangat 15 menit setelah mengkonsumsi air hangat peneliti melakukan pengukuran frekuensi pernafasan penderita asma.

\section{HASIL PENELITIAN}

\section{Analisis Univariat}

Analisis univariat untuk memperoleh gambaran variabel, yang di gambarkan dalam bentuk tabel dengan tujuan mengetahui gambaran jenis kelmain, usia dan lama menderita asma pada pasien asma di Puskesmas Sukamerindu Kota Bengkulu.

Tabel 1 Gambaran Karakteristik Pasien Penderita Asma di Puskesmas Sukamerindu Kota Bengkulu Tahun 2019

\begin{tabular}{cccc}
\hline No & Variabel & $\begin{array}{c}\text { Frekuensi } \\
\text { (f) }\end{array}$ & $\begin{array}{c}\text { Persentase } \\
(\mathbf{\%})\end{array}$ \\
\cline { 3 - 4 } & & & \\
\hline 1 & Laki-Laki & 19 & 67,9 \\
\hline 2 & Perempuan & 9 & 32,1 \\
\hline & Jumlah & 28 & 100 \\
\hline & Usia & & \\
\hline 1 & $<19$ tahun & 6 & 21,4 \\
\hline 2 & $\geq 19$ tahun & 22 & 78.6 \\
\hline & Jumlah & 28 & 100 \\
\hline & Lama Menderita & Frekuensi & Persentase \\
& & $(\mathbf{f})$ & $\mathbf{( \% ) ~}$ \\
\hline 1 & $<5$ tahun & 18 & 64,3 \\
\hline 2 & $\geq 5$ tahun & 10 & 35,7 \\
\hline & Jumlah & 28 & 100,0 \\
\hline & \multicolumn{2}{c}{}
\end{tabular}

Berdasarkan tabel 1 dapat diketahui bahwa karakteristik penderita asma di Puskesmas Sukamerindu Kota Bengkulu yaitu sebagian besar atau 19 orang $(67,9 \%)$ berjenis kelamin laki-laki, pada umumnya atau 22 orang $(78,6 \%)$ berusia $\geq 19$ tahun dan lama menderita asma sebagian besar atau 18 orang $(64,3 \%)<5$ tahun.

Tabel 2 Rata-rata frekuensi nafas sebelum dan sesudah pada kelompok control di Puskesmas Sukamerindu Kota Bengkulu Tahun 2019

\begin{tabular}{cccc}
\hline $\begin{array}{c}\text { Frekuensi } \\
\text { Nafas } \\
\text { Kelompok } \\
\text { Kontrol }\end{array}$ & Mean & Min-Mix & SD \\
\hline Sebelum & 26,42 & $25,0-29,0$ & 1,22 \\
\hline Setelah & 26,50 & $25,0-29,0$ & 1,22 \\
\hline
\end{tabular}

Dari tabel 2 dapat diketahui bahwa pada kelompok kontrol terdapat peningkatan frekuensi pernafasan yaitu sebelum dengan mean $(26,4286)$ dan setelah dengan mean $(26,50)$ di Puskesmas Sukamerindu Kota Bengkulu Tahun 2019

Tabel 3. Rata-rata frekuensi nafas sebelum dan sesudah pada kelompok intervensi di Puskesmas Sukamerindu Kota Bengkulu Tahun 2019 


\begin{tabular}{ccccc}
\hline $\begin{array}{c}\text { Frekuensi Nafas } \\
\text { Kelompok } \\
\text { Intervensi }\end{array}$ & Mean & $\begin{array}{c}\text { Min- } \\
\text { Mix }\end{array}$ & SD & $\mathbf{9 5 \% C I}$ \\
\hline Sebelum & 26,92 & $25,0-$ & 1,63 & $25,98-$ \\
& & 30,0 & & 27,87 \\
\hline Setelah & 22,28 & $20,0-$ & 1,72 & $21,28-$ \\
& & 26,0 & & 23,28 \\
\hline
\end{tabular}

sudah diolah (2019)

Dari tabel 3 dapat diketahui bahwa pada kelompok intervensi terdapat peniurunan frekuensi pernafasan yaitu sebelum intervensi dengan mean $(26,92)$ dan setelah intervensi dengan mean $(26,28)$ di Puskesmas Sukamerindu Kota Bengkulu Tahun 2019

\section{Analisa Bivariat}

Analisis bivariat dilakukan untuk mengetahui hubungan antara variabel independen dengan variabel dependen yaitu perbedaan frekuensi nafas pada pasien asma kelompok intervensi dan kelompok kontrol di Puskesmas Sukamerindu Kota Bengkulu Tahun 2019 dapat dilihat pada tabel berikut:

Tabel 4. Pengaruh Konsumsi Air Hangat terhadap Frekuensi Nafas Pada pasien asma Kelompok Kontrol Di Puskesmas Sukamerindu Kota Bengkulu Tahun 2019

\begin{tabular}{|c|c|c|c|c|}
\hline Variabel & Mean & $\begin{array}{c}\text { Std. } \\
\text { Deviatio } \\
\mathbf{n}\end{array}$ & $\begin{array}{c}\text { CI } \\
95 \%\end{array}$ & $\begin{array}{c}P \\
\text { Valu } \\
e\end{array}$ \\
\hline $\begin{array}{l}\text { Frekuensi Nafas sebelum } \\
\text { Frekuensi Nafas Setelah }\end{array}$ & $-0,07$ & 0,61 & $\begin{array}{c}-42- \\
28\end{array}$ & 0,671 \\
\hline
\end{tabular}

Berdasarkan tabel 4 di atas menunjukkan bahwa dari hasil uji t-dependen nilai mean $-0,07$ dan $\mathrm{SD}=0,61$. Dari hasil uji statistic didapatkan nilai $p$ value $=0,671$, maka dapat disimpulkan bahwa tidak ada pengaruh frekuensi nafas pada pasien asma sebelum dan setelah pada kelompok kontrol (tidak konsumsi air hangat) di Puskesmas Sukamerindu Kota Bengkulu Tahun 2019

Tabel 5. Pengaruh Konsumsi Air Hangat terhadap Frekuensi Nafas Pada pasien asma Kelompok Intervensi Di Puskesmas
Sukamerindu Kota Bengkulu Tahun 2019

\begin{tabular}{ccccc}
\hline Variabel Mean & $\begin{array}{c}\text { Std. } \\
\text { Deviation }\end{array}$ & CI 95\% & $\begin{array}{c}\boldsymbol{P} \\
\text { Value }\end{array}$ \\
\hline $\begin{array}{c}\text { Frekuensi Nafas } \\
\text { sebelum }\end{array}$ & & & \\
$\begin{array}{c}\text { Frekuensi Nafas } \\
\text { Setelah }\end{array}$ & & 0,64 & $4.10-$ & \\
\hline
\end{tabular}

Berdasarkan tabel 5 di atas menunjukkan bahwa dari hasil uji t-dependen mean $(4,64)$ dengan SD $(0,92$, sehingga hasil uji statistic didapatkan nilai $p$ value $=0,000$, maka dapat disimpulkan bahwa ada pengaruh frekuensi nafas pada pasien asma sebelum dan setelah pada kelompok intervensi di Puskesmas Sukamerindu Kota Bengkulu Tahun 2019.

Tabel 6. Pengaruh konsumsi air hangat terhadap frekuensi nafas pada pasien asma antar kelompok intervensi dan kelompok kontrol di Puskesmas Sukamerindu Kota Bengkulu Tahun 2019

\begin{tabular}{ccccc}
\hline Variabel & Mean & Std. Eror & CI 95\% & $\begin{array}{c}\boldsymbol{P} \\
\text { Value }\end{array}$ \\
\hline $\begin{array}{c}\text { Post Intervensi } \\
\text { Post Kontrol }\end{array}$ & $-4,21$ & 0.56 & $\begin{array}{c}-5.37- \\
-3.05\end{array}$ & 0,000 \\
\hline
\end{tabular}

Berdasarkan Tabel di atas didapatkan bahwa dari uji t Independen di dapatkan nilai $p$ value $=0,000$ maka Ha diterima, artinya ada perbedaan frekuensi nafas pada pasien asma kelompok intervensi dan kelompok kontrol di Puskesmas Sukamerindu Kota Bengkulu Tahun 2019, serta dapat dilihat bahwa frekuensi nafas pada kelompok intervensi rata-rata 22,28 lebih rendah dibandingkan kelompok kontrol sebesar 26,50 yang menunjukkan bahwa terjadi penurunan frekuensi nafas pada pasien asma setelah diberikan air hangat.

\section{PEMBAHASAN}

\section{Analisis Univariat}

a. Gambaran Karakteristik Pasien 


\section{Penderita Asma di Puskesmas Sukamerindu Kota Bengkulu Tahun 2019}

Hasil penelitian ini diketahui bahwa karakteristik penderita asma di Puskesmas Sukamerindu Kota Bengkulu yaitu jenis kelamin penderita asma sebagian besar atau 19 orang $(67,9 \%)$ laki-laki dan 9 orang sebagian kecil atau (32,1\%) perempuan, sebagian kecil atau 6 orang $(21,4 \%)$ berusia $\geq 19$ tahun dan pada umumnya atau 22 orang $(78,6 \%)$ berusia $\geq 19$ tahun, lama menderita asma sebagian besar atau 18 orang $(64,3 \%)$ $<5$ tahun dan sebagian kecil atau 10 orang $(35,7 \%) \geq 5$ tahun.

Hasil penelitian ini menunjukkan bahwa laki-laki lebih banyak mengalami asma yang disebabkan karena faktor merokok dan paparan polusi udara, selain itu mayoritas berusia diatas 19 tahun hal ini disebabkan karena paparan polusi dengan tambahan umur akan semakin meningkat, di dukung dengan hasil penelitian ini bahwa responden mayoritas menderita asma $<5$ tahun hal ini menunjukkan bahwa paparan udara atau polusi udara yang mempengaruhi terjadinya asma pada penderita asma. Menurut Kemenkes RI (2009) bahwa sebagian besar serangan asma dimulai sejak masa kanakkanak dan menetap hingga usia lanjut. Namun beberapa serangan asma justru muncul setelah dewasa karena faktor ekstrinsik di lingkungan kerja maupun rumah yang paling utama ialah polusi udara dari asap rokok, kenderaan dan pembakaran hutan, limbah atau sampah.

Jenis asma yang paling sering diderita oleh anak-anak berusia di bawah 3 tahun dan dewasa berusia di atas 30 tahun. Infeksi pernafasan karena virus merupakan pemicu utama pernafasan karena virus merupakan pemicu utama dan mempengaruhi, baik saraf dan atau saluran pernafasan (bronchi). Menurut Muttaqin (2008) Jumlah kejadian asma pada laki-laki lebih banyak dibandingkan dengan perempuan.

Hasil penelitian ini sejalan dengan penelitian yang dilakukan oleh Sri Hartati (2014) dengan judul karakteristik penderita asma yang dirawat inap di Rumah Sakit
Umum Dr. Pirngadi Medan menyatakan bahwa sebagian besar penderita asma berjenis kelamin laki-laki $(51,3 \%)$, berusia diatas 19 tahun (60,8\%), bekerja dipabrik (67\%).

\section{b. Rata-rata frekuensi nafas sebelum dan sesudah pada kelompok control di Puskesmas Sukamerindu Kota Bengkulu Tahun 2019}

Hasil penelitian ini diketahui bahwa pada kelompok kontrol terdapat peningkatan frekuensi pernafasan yaitu sebelum dengan mean $(26,42)$ dan setelah dengan mean $(26,50)$ di Puskesmas Sukamerindu Kota Bengkulu Tahun 2019, artinya pada penelitian ini diketahui bahwa tidak ada perubahan pada kelompok kontrol rata-rata pasien mengalami asma sedang.

Menurut PDPI (2016) asma derajat sedang ditandai dengan frekuensi pernafasan 26-30 x/menit dengan gejala sesak nafas mulai terasa pada saat beraktifitas terkadang terdapat gejala batuk dan produksi sputum. Biasanya pasien mulai memeriksakan kesehatannya pada derajat ini. Asma ialah penyakit paru dengan ciri khas yakni saluran napas sangat mudah bereaksi terhadap berbagai rangsangan atau pencetus dengan manifestasi berupa serangan asma (Ngastiyah, 2011). Kalainan yang didapatkan adalah otot bronkus akan mengkerut (terjadi penyempitan) dan selaput lendir bronkus edema.

Sejalan dengan penelitian Purwaningsih (2017) menyebutkan bahwa pada kelompok kontrol (tidak konsumsi air hangat) diketahui rata-rata derajat sesak napas pada pre test sebesar 26,53 yang berarti sesak napas sedang dan post test sebesar 26,40 yang berarti sesak napas sedang artinya tidak mengalami perubahan frekeunsi pernafasan di Balai Besar Kesehatan Paru Masyarakat Surakarta

\section{c. Rata-rata frekuensi nafas sebelum dan sesudah pada kelompok intervensi di Puskesmas Sukamerindu Kota Bengkulu Tahun 2019}


Hasil penelitian ini diketahui bahwa pada kelompok intervensi terdapat peniurunan frekuensi pernafasan yaitu sebelum intervensi dengan mean $(26,92)$ dan setelah intervensi dengan mean $(26,28)$ di Puskesmas Sukamerindu Kota Bengkulu Tahun 2019, artinya pada penelitian ini terlihat adanya perubahan setelah mengkonsumsi air hangat.

Menurut Batmanghelidj (2012) sebuah aspek penting dari penemuan tentang air putih hangat dalam keperawatan merupakan tindakan mandiri yang dapat dipergunakan sebagai penatalaksanaan non farmakologis utuk mengobati masalah kesehatan pasien dengan tanpa bahan-bahan kimia atau tanpa tindakan invasif. Termasuk dalam memberi nutrisi pada pasien, yang tidak disertai dengan konsumsi air maka akan menghasilkan kerentanan terhadap alergi. Darah yang kental dalam tubuh akan menjadikan kerja makanan sangat berat sehingga harus beredar melalui paru-paru dan melepaskan beberapa lagi melalui penguapan di pernapasan.

Sejalan dengan penelitia Kusumawati (2012) bahwa pada kelompok intervensi (konsumsi air) hangat, terjadi penurunan frekuensi pernafasan pada pasien penderita asma setelah diberikan terapi air hangat, sedangkan pada kelompok kontrol (tidak konsumsi air hangat) tidak ada penurunan frekuensi pernafasan.

\section{Analisis Bivariat}

\section{a. Pengaruh Konsumsi Air Hangat terhadap Frekuensi Nafas Pada pasien asma Kelompok Kontrol Di Puskesmas Sukamerindu Kota Bengkulu Tahun 2019}

Hasil penelitian ini diketahui dari hasil uji $t$-dependen nilai mean $-0,07$ dan $\mathrm{SD}=0,61$. Dari hasil uji statistic didapatkan nilai $p$ value $=0,671$, maka dapat disimpulkan bahwa tidak ada pengaruh frekuensi nafas pada pasien asma sebelum dan setelah pada kelompok kontrol (tidak konsumsi air hangat) di Puskesmas Sukamerindu Kota Bengkulu Tahun 2019.
Menurut Sari (2016) masalah yang diakibatkan oleh asma jika tidak dilakukan pengobatan dan pencegahan adalah adanya penumpukan sputum pada saluran pernapasan. Beberapa gejala klinis akibat penumpukan sputum ini adalah pernapasan cuping hidung, peningkatan respiratory rate, dyspnea, timbul suara krekels saat diauskultasi, dan kesulitan bernapas. Kesulitan bernapas akan menghambat pemenuhan suplai oksigen dalam tubuh sehingga suplai oksigen berkurang. Berkurangnya suplai oksigen dalam tubuh akan membuat kematian sel, hipoksemia dan penurunan kesadaran. Penanganan pada pasien asma dengan masalah kebersihan jalan napas bertujuan untuk membersihkan saluran pernapasan sehingga suplai oksigen yang masuk ke dalam tubuh dapat terpenuhi dan gangguan akibat berkurangnya suplai oksigen tidak terjadi.

Sejalan dengan penelitian Rahayu (2015) menyebutkan bahwa dari hasil uji statistik menggunakan Wilcoxon Sign Rank Test dengan tingkat kepercayaan 95\% dan $\mathrm{I}=0,05$, didapatkan nilai signifikan $\mathrm{p}$ value $=1,000$ atau lebih besar dari 0,05 . Nilai p-value lebih besar dari 0,05 yang berarti tidak terdapat pengaruh yang signifikan terhadap kelancaran jalan nafas kelompok kontrol (pre test) dan (post test) sebelum tindakan nebulizer.

\section{b. Pengaruh Konsumsi air hangat terhadap frekuensi nafas Pada pasien asma Kelompok Intervensi Di Puskesmas Sukamerindu Kota Bengkulu Tahun 2019}

Hasil penelitian ini diketahui dari hasil uji t-dependen mean $(4,64)$ dengan $\operatorname{SD}(0,92$, sehingga hasil uji statistic didapatkan nilai $p$ value $=0,000$, maka dapat disimpulkan bahwa ada pengaruh frekuensi nafas pada pasien asma sebelum dan setelah pada kelompok intervensi di Puskesmas Sukamerindu Kota Bengkulu Tahun 2019..

Didukung teori Doengos (2008) menyebutkan bahwa pengobatan secara sederhana atau non farmakologis, 
penatalaksanaan nonfarmakologis asma yaitu dengan memberikan minum air putih hangat 1500-2000 ml per hari. Air adalah zat atau unsur yang paling penting bagi semua bentuk kehidupan didunia ini. yang kita ketahui sampai saat ini dibumi, air merupakan zat cair yang tidak mempunyai rasa, warna dan bau. Air sebagai sumber daya adalah air yang dibutuhkan oleh semua kehidupan, baik tumbuhan, mikroorganisme maupun manusia. Agar tetap dapat kita pakai air harus dijaga supaya tidak tercemar, karena sifat air yang mudah berubah baik dari segi bentuk, ukuran dan rasa warna dari lingkungannya yang mempengaruhinya, apa lagi jika lingkungan yang tercemar maka air juga akan mudah sekali tercemar. Konsumisi air hangat merupakan konsumsi air dengan suhu 38$40^{\circ} \mathrm{C}$. Konsumsi air hangat dilakukan perlahan selama 5 menit dapat membebaskan jalan nafas, sehingga dapat menjadi terapi pada penderita asma.

Sejalan dengan penelitian Majampoh (2013) menyebutkan bahwa frekuensi pernapasan sebelum diberikan air hangat termasuk frekuensi sesak napas sedang sampai berat dan frekuensi pernapasan setelah diberikan konsumsi air hangat termasuk frekuensi pernapasan normal. Simpulan Terdapat pengaruh pemberian konsumsi air hangat terhadap kestabilan pola napas pada pasien sesak nafas dengan nilai $p$ value $=$ 0,000 .

\section{c. Pengaruh konsumsi air hangat terhadap frekuensi nafas pada pasien asma kelompok intervensi dan kelompok kontrol di Puskesmas Sukamerindu Kota Bengkulu Tahun 2019}

Berdasarkan Tabel di atas didapatkan bahwa dari uji Independen dengan nilai $p$ value $=0,000$ maka Ho diterima, artinya ada perbedaan frekuensi nafas pada pasien asma kelompok intervensi dan kelompok kontrol di Puskesmas Sukamerindu Kota Bengkulu Tahun 2019, serta dapat dilihat bahwa frekuensi nafas pada kelompok intervensi rata-rata 22,28 lebih rendah dibandingkan kelompok kontrol sebesar 26,50 yang menunjukkan bahwa terjadi penurunan frekuensi nafas pada pasien asma setelah diberikan air hangat.

Usaha yang dapat dilakukan dalam pengobatan penyakit asma dapat dilakukan dengan cara farmakologi dan non farmakologi. Pengobatan farmakologis pada asma biasanya dengan oksigenisasi dan melibatkan pengobatan beta 2 adrenergik, sedangkan pengobatan nonfarmakologis biasanya dengan menghindari faktor penyebab dan menciptakan lingkungan yang sehat, selain itu dalam mengurangi gejala asma dan memperbaiki kualitas hidup yaitu dengan terapi pemberian air hangat. Teknik farmakologi memiliki banyak efek samping, sedangkan pengobatan dengan non farmakologi kurang memiliki efek samping (Doenges, 2010).

Pemberian minum air putih hangat memberikan efek hidrostatik dan hidrodinamik dan hangatnya membuat sirkulasi peredaran darah khususnya pada daerah paru-paru agar menjadi lancar. Secara fisiologis, air hangat juga memberi pengaruh oksigenisasi dalam jaringan tubuh (Hamidin, 2012). Hal serupa diungkapkan oleh Yuanita (2011), minum air hangat dapat memperlancar proses pernapasan, karena pada pernapasan pasien asma membutuhkan suasana yang encer dan cair. Pada penderita asma minum air hangat sangat tepat untuk membantu memperlancar pernapasan karena dengan minum air hangat partikel-partikel pencetus sesak dan lendir dalam bronkioli akan dipecah dan menyebabkan sirkulasi pernapasan menjadi lancar sehingga mendorong bronkioli mengeluarkan lendir.

Sejalan dengan penelitian yang dilakukan oleh Adiputra (2017) menyebutkan bahwa dari hasil uji Wilcoxon didapatkan $p$ value sebesar 0,002, yang menunjukkan bahwa terdapat pengaruh pemberian air minum hangat sebelum tindakan nebulizer terhadap kelancaran jalan nafas dan frekuensi pernapasan pada pasien asma. Hasil uji Mann Whitney didapatkan $p$ value sebesar 0.029, artinya terdapat perbedaan 
pengaruh pemberian air minum hangat sebelum tindakan nebulizer terhadap kelancaran jalan nafas

\section{KESIMPULAN}

Karakteristik penderita asma di Puskesmas Sukamerindu Kota Bengkulu yaitu dari 28 responden sebagian besar atau19 orang $(67,9 \%)$ berjenis kelamin laki-laki, pada umumnya atau 22 orang $(78,6 \%)$ berusia $\geq 19$ tahun dan lama menderita asma sebagian besar atau 18 orang $(64,3 \%)<5$ tahun.

1. Rata-rata frekuensi pernafasan sebelum $(26,4286)$ dan setelah $(26,50)$ pada kelompok kontrol di Puskesmas Sukamerindu Kota Bengkulu Tahun 2019

2. Rata-rata frekuensi pernafasan sebelum $(26,92)$ dan setelah $(26,28)$ pada kelompok intervensi di Puskesmas Sukamerindu Kota Bengkulu Tahun 2019

3. Ada pengaruh konsumsi air hangat terhadap frekuensi nafas pada pasien asma pada kelompok intervensi di Puskesmas Sukamerindu Kota Bengkulu Tahun 2019

4. Tidak ada pengaruh konsumsi air hangat terhadap frekuensi nafas pada pasien asma pada kelompok kontrol di Puskesmas Sukamerindu Kota Bengkulu Tahun 2019

5. Ada perbedaan frekuensi nafas pada pasien asma kelompok intervensi dan kelompok kontrol di Puskesmas Sukamerindu Kota Bengkulu Tahun 2019

\section{SARAN}

Diharapkan kepada peneliti selanjutnya untuk melakukan penelitian dengan metode dan desain yang berbeda.

\section{DAFTAR PUSTAKA}

Agustina. 2015. Pengaruh Terapi Bermain Super Bubbles Terhadap Kecemasan Akibat Hospitalisasi Pada Anak Penderita Asma Usia Prasekolah Di RSUD Surakarta. Dari http://eprints.ums.ac.id.pdf. Jurnal [2
Desember 2018]

Amin dan Hardhi. 2016. Asuhan Keperawatan Berdasarkan Diagnosa Medis \& NANDA Jilid I dan II. Jogjakarta. Mediaction Jogja.

Dinkes Kota Bengkulu. 2018. Profil Dinas KesehatanKota Bengkulu Tahun 2018. Bengkulu

Doenges. 2010. Rencana Asuhan Keperawatan Alih Bahasa. (diakses 09 Februari 2018), diunduh dari http://eprints.ums.ac.id/21070/26/naska $\mathrm{h} \_$publikasi.pdf.

Ekarini. 2012. Analisis Faktor-Faktor Pemicu

Dominan Terjadinya Serangan Asma Pada Paien Asma. FIK UI. 108.

Kemenkes. 2018. Profil data Kesehatan Indonesia Tahun 2018. Jakarta

Infodatin. 2017. Pusat Data dan Informasi Kesehatan RI. Jakarta: ISSN 24427659.

Irianto. 2014. Epidemiologi Penyakit Menular dan Tidak menular Panduan Klinis. Bandung; Penerbit Alfabeta

Kemenkes. 2016. Infodatin Asma. Kemenkes RI: Jakarta

Kemenkes. 2017. Hasil Penelitian Riset Kesehatan Dasar. Indonesia: Kemenkes RI.

Kowalak et all. 2011. Buku Ajar Patofisiologi. Jakarta: EGC

Medicastore. 2013. Faktor-Faktor Pemicu Dominan Terjadinya Serangan Asma Pada Paien Asma. Dari http://lib.ui.ac.id/file? file $=$ digital $/ 20303000-T 30663 \% 20$ \%20Analisis\%20faktor.pdf. Skripsi [2 Februari 2019]

Ngastiyah. 2011. Perawatan Anak Sakit. Jakarta: Penerbit Buku Kedokteran EGC.

Notoatmodjo, S. 2012. Metode Penelitian Kesehatan. Jakarta: PT. Rineka Cipta.

Padila. 2013. Asuhan Keperawatan Penyakit Dalam. Yogyakarta: Nuha Medika

Riyanto, A. 2017. Aplikasi Metodologi Penelitian Kesehatan. Yogyakarta: Nuha Medika

Sari. 2014. Pengaruh Terapi Bermain 
Gelembung Super Terhadap Tingkat Kecemasan Pada Anak Usia Prasekolah Yang Mengalami Hospitalisasi Di

Ruang Anak Rsud Pandan Arang Boyolali. Dari http://eprints.ums.ac.id / 28788/17

/NASKAH_PUBLIKASI.pdf. Jurnal [22 Desember 2018]

Sulistyaningsih. 2011. Metode Penelitian Kebidanan Cetakan ke-2. Yogyakarta: Graha Ilmu 